\title{
The Application of Caveat Emptor and Caveat Venditor Doctrines from Civil and Islamic Perspectives
}

\author{
Muhammad Hafiz Mohd. Shukri \\ RAHMAH ISMAIL \\ RUZIAN MARKOM
}

\begin{abstract}
Since a long time ago, consumers have never been completely safe from exposure to the risk of purchasing defective products, which may cause an adverse effect on them. The introduction of the doctrines of caveat emptor and caveat venditor became a part of the common law to resolve disputes between manufacturers, sellers, and consumers. This study therefore aims to analyze the application of the caveat emptor and caveat venditor doctrines according to civil and Islamic perspectives to see how far the application of both doctrines can provide justice to consumers. Utilizing doctrinal approach based on the methodology of qualitative legal research, this study involves in-depth analysis of statutory provisions, court cases, Quranic texts, hadiths, and the opinions of Muslim scholars. The research findings were analyzed through content analysis and critical analysis methods. This study has proven that there are legal problems with regards to the application of the caveat emptor doctrine and its resulting negative impact on consumers, thus leading to the formation of the caveat venditor doctrine. Although the term "caveat venditor" and its definition are not expressly mentioned in the Qur'an and the hadiths, the application of the doctrine is seen to have a strong foundation in Islam. The results of this study are expected to contribute significant new knowledge in the field of consumer law since a comparative analysis of the application of both doctrines according to civil and Islamic perspectives is still lacking, especially in cases involving the selling of defective products.
\end{abstract}

Keywords: Caveat emptor; caveat venditor; civil; consumer protection; khiyar

\section{INTRODUCTION}

Section 3 of Consumer Protection Act 1999 (CPA 1999) 1 interprets the term "consumer" as a person who acquires or uses goods or services for personal or household purposes. However, this provision has placed a limit on the type of goods or services obtained. As such, a person is a "consumer" according to the CPA 1999 if he obtains goods or services for individual or household purposes. ${ }^{2}$

Over the years, the existence of consumers is considered as one of the important elements of a business entity as it is a key factors in determining the ups and downs of a business. ${ }^{3}$ However, in reality, consumers are exposed to the risk of misconduct by manufacturers such as the production of defective products ${ }^{4}$ and the provision of unsatisfactory services ${ }^{5}$ which adversely affect consumers. ${ }^{6}$ In fact, most consumers, including children, do not usually know $^{7}$ or do not clearly understand the types of chemicals used to produce a product ${ }^{8}$ and its impact on human life in the long run. For example, in 2007, a children's toy called "Aqua Dots" was found to have a coating that could react by producing a dangerous drug if swallowed by a child. Aqua Dots was eventually withdrawn from the market after a few children fell ill and were hospitalized due to their swallowing of the toy while playing. The results of the doctor's examination proved that there was a direct relationship, namely the causation element connecting the side effects experienced by the child, and the dangerous drugs resulting from the reaction to the Aqua Dots layer. ${ }^{9}$

Accordingly, comprehensive protection of consumers from a legal point of view is essential to control the sale of unsafe products ${ }^{10}$ and balance the position of consumers in business activities. ${ }^{11}$ Indirectly, these are among the goals of consumer law formulation, which are to provide platform to protect consumers ${ }^{12}$ and remedies to those who suffer losses because of defective products or irresponsible acts committed by the manufacturer or seller. ${ }^{13}$

The absence of a clear legal principle to resolve the issue of the seller's responsibility with 
regards to the requirement to disclose information of a product to consumers influenced the position of English law to introduce the Latin doctrines of "caveat emptor" and "caveat venditor" in business transactions. ${ }^{14}$ Thus, the main objective of this study is to analyze the application of caveat emptor and caveat venditor doctrines from the perspectives of civil consumer law and Islamic law of transaction in achieving justice to consumers in cases involving the sale of defective products and products that do not meet the needs of consumers. The findings are expected to significantly provide new contributions in the context of consumer law.

\section{CAVEAT EMPTOR FROM CIVIL PERSPECTIVES}

The Latin term "caveat emptor" can be literally defined as "let the buyer beware". ${ }^{15}$ The linguistic point of view defined the term "caveat" or "cavere" as buyer, while the term "emptor" as vigilance. Meanwhile, the complete definition of caveat emptor is "let the purchaser, who ought not to be ignorant of the amount and nature of the interest, exercise proper caution". ${ }^{16}$

The usage of this classic term was discovered in writing for the first time in 1534 and applied in the sale and purchase of livestock. ${ }^{17}$ Historically, the usage of the term began in England around the 16th century. At that time, most business affairs only took place among family members and close friends, while business affairs involving outsiders took place at festival sites in urban areas. However, the authorities' refusal at the time to provide adequate protection to consumers through legislation eventually resulted in the term "caveat emptor" gaining a place in business. ${ }^{18}$ After that, the term "caveat emptor" was introduced and applied in court to resolve disputes between sellers and buyers. ${ }^{19}$ The application of the doctrine of caveat emptor considered as one of the methods in minimizing the increasing number of consumer lawsuits against sellers in England. Later, the application of the doctrine of caveat emptor extended to the United States from the $19^{\text {th }}{ }^{20}$ until the mid-20th century. ${ }^{21}$

In practice, this doctrine requires the parties involved in a sale of goods contract namely the consumer to always beware before buying a product. They should always ensure the intended products are free from any defects. ${ }^{22}$ In other words, the consumer is responsible for inspecting the product which he or she bought. ${ }^{23}$ This is because when buying the product, the consumer is considered to have used his or her discretion accordingly before making any decision to buy it. ${ }^{24}$ Therefore, if the purchased product is found to have defects after the purchase is made, the consumer should be responsible and should not blame the seller. ${ }^{25}$

According to Thomas Aquinas, the leading philosophers in the field of law and ethics, if the consumer accepts the defect product despite the existence of defects in the product is clear and visible logically, then the seller is not legally bound to inform the consumer of the existence of such defects in advance. ${ }^{26}$ Thus, the doctrine of caveat emptor will apply, and the consumer shall be responsible for all defects found after the purchase of the product is completed. In fact, consumers cannot cancel the contract, return the purchased product, and no damages can be claimed against the seller. ${ }^{27}$

The application of the caveat emptor doctrine can be analyzed through several examples of previous court cases. For example, in the case of Chandelor v Lopus, ${ }^{28}$ a goldsmith in London (defendant) had sold a bezar-stone gemstone as alleged by the defendant to the plaintiff for 100 pounds sterling. However, the plaintiff eventually found that the gemstone was not a bezar-stone type as alleged by the defendant. The plaintiff then filed the case in court. The court stated that the defendant gave no guarantee as to the authenticity of the gemstone. In fact, there was no evidence to show that the defendant knew the type of gemstone was not a bezar-stone type. Thus, the defendant was found not guilty, and no award of damages was given to the plaintiff in this case. This case shows that the court did not place any responsibility on the defendant to disclose information about the authenticity of the gemstone to the plaintiff. Indirectly, the doctrine of caveat emptor was therefore clearly applied by the court.

On the other hand, in the case of Stuart $v$ Wilkins, ${ }^{29}$ the court stated that the sale of a product accompanied by a guarantee will warrant the sale of a product to be free from all forms of defects regardless of whether the defect is known to the seller or not. However, if there is no guarantee, then the doctrine of caveat 
emptor will apply in the sale and purchase contract.

In fact, a similar approach was taken by the court in the case of Barnard $v$ Kellogg. ${ }^{30}$ The defendant was a yarn seller, and often marketed the yarn he produced through a broker. At one point, the broker who was representing the defendant sent several samples of yarn to the plaintiff. The broker then accepted the plaintiff's offer to purchase the yarn from him on the condition that the plaintiff must inspect the yarn he wishes to purchase first. After that, a representative on behalf of the plaintiff inspected part of the package of yarn placed at the broker's office, but rejected the opportunity given to him to inspect all the packages, and subsequently finalized the purchase of the desired yarn. A few months later, the plaintiff found that there were several packages containing damaged yarns. Unfortunately, the situation was unknown to the defendant, and the defendant rejected the plaintiff's claim to pay damages to him. The court ruled that the yarns were not sold on a sample basis and if the plaintiff had wished to avoid any loss, he should have tried to obtain a guarantee from the defendant or inspected all the yarn packages shown to him first before finalizing the purchase. The opportunity given by the defendant to the plaintiff to inspect all the packages of the yarn before finalizing the purchase also rejected the plaintiff's argument to categorize this purchase as a purchase by sample. Thus, the principle of caveat emptor was applied, and proved that the approach of the court was in line with the approach taken by the court in the case of Stuart v Wilkins.

Furthermore, the doctrine of caveat emptor will not apply in the following exceptions. Firstly, if the existence of defects in a product cannot be identified through self-inspection by the consumer and at the same time the seller also conceals its existence. ${ }^{31}$ Secondly, the seller was asked by the consumer to disclose all defects that exist in a product before purchase. Therefore, for the second exception, the seller is responsible for disclosing any defects which exist in a product, if any, to the consumer after being asked to do so by the consumer before the process of purchasing goods occurs. ${ }^{32}$ Thirdly, the existence of guarantee of the purchased product and finally, the seller has issued a false statement about the product with an intention to commit fraud. ${ }^{33}$

The relevance of the application of the caveat emptor doctrine in the sale and purchase of goods is further evaluated by Western studies, especially from the legal point of view, to provide more effective protection to consumers, and adapt it to the needs of the industry. The studies revealed that there is a need to disclose information about the condition of a house or building to consumers in real estate transactions. The information on the presence of termites in a house or building to be rented or sold should be given to potential tenants or buyers in advance before a contract is signed to prevent any unfortunate incidents in the future. The presence of termites is also one of the examples of latent defects that cannot be detected through normal inspection by consumers and is categorized as the opposite of obvious defects that can be found through normal inspection by consumers. ${ }^{34}$ Thus, the caveat emptor application in the above situation is feared to cause injustice to consumers.

\section{CAVEAT EMPTOR FROM ISLAMIC PERSPECTIVE}

In general, the doctrine of caveat emptor is seen to be related to one of the principles in Islamic law of transaction, namely "khiyar". Sheikh Daud bin Abdullah al-Fatani has argued in his book Furu 'al-Masa'il that the term "khiyar" or option, generally refers to the specific rights given to the contracting parties whether to continue with the contract or terminate the contract which has been agreed. The application of khiyar principle in business transactions is intended to safeguard the interest of both parties involved and to ensure that the contract is carried out voluntarily. ${ }^{35}$ Specifically, there are four main types of khiyar which have been much discussed in the books of fiqh such as khiyar al-syarat, khiyar al-ru'yah, khiyar al-majlis and khiyar al-ayb. ${ }^{36}$ Next, the researchers will briefly discuss the definition of each type of khiyar as mentioned above to identify the most relevant type of khiyar for the purpose of comparison with the application of caveat emptor doctrine.

According to fiqh perspective, khiyar al-syarat gives the right to the contracting 
parties whether or not to continue or cancel the contract within three days if the option has been provided in the contract. Thus, the application of khiyar al-syarat will allow consumers to better understand the content of the contract because they have been allocated enough time $^{37}$ to decide whether or not to continue or cancel the contract.

Meanwhile, khiyar al-ru'yah is an option given to the consumer whether to continue the contract or cancel it after seeing the purchased goods which he did not see before or while making the contract. The Hanafi school argued that the activity of buying and selling unseen goods is legal and the risk faced by the consumer is minimal as the consumer has the right to choose whether to accept the goods which have arrived or cancel the contract. However, Imam Shafie did not agree because the transaction was found to have an element of gharar as the nature of the goods was not known in advance by the consumer, that is, before or during the contract. ${ }^{38}$

On the other hand, khiyar al-majlis allocates the right to the contracting parties whether to continue or cancel the contract from the period after the contract is finalized until before they leave the contracting session. According to Syafie and Hanbali madhabs, the application of khiyar al-majlis is valid to provide an opportunity for the contracting parties to think deeply about the decision taken in the contract. However, according to Hanafi and Maliki madhabs, the application of khiyar al-majlis is not recognized since the contract will be considered as final and binding if the elements of offer and acceptance have taken place. ${ }^{39}$ Thus, the researchers found that the Syafie and Hanbali madhabs still provide flexibility to the contracting parties to continue or cancel the contract until before they leave the contracting session even though the contract has been finalized based on the existence of offer and acceptance elements.

According to Imam al-Nawawi, khiyar $a l-a i b$ is an option given to consumers whether they want to continue the sale or purchase agreement or not after finding any defects in a product that existed while the product is still with the seller or before the product is accepted by the consumer. In addition, the discovery timeframe of the existence of a product defect can occur either before or after the completion of the purchase process. ${ }^{40}$ Therefore, the studies found that the principle of khiyar al-aib can be applied when the existence of a defect in a product was discovered by the consumer, either before or after the process of purchasing the product occurs, if the defect has existed earlier, which is before the product is accepted by the consumer.

As such, among four major types of khiyar, the researchers viewed that the principle of khiyar al-aib is the most relevant Islamic principle to be compared with the doctrine of caveat emptor in terms of its features and application. It is because generally, the application of caveat emptor requires the consumer to ensure that the intended products are free from any defects while at the same time, the principle of khiyar al-aib can also be applied when the existence of a defect in a product was discovered by the consumer. The specific differences between both principles will be analysed by the researchers in the next part of this paper.

\section{DISTINCTIVE FEATURES OF THE PRINCIPLE OF KHIYAR AL-AIB}

In elaborating the distinctive features of the principle of khiyar al aib, it is worth to compare it with the doctrine of caveat emptor. The essential feature of the principle of khiyar al aib is the defective product. Article 338 of Majallah al-Ahkam al-'Adliyyah defines defect as "what reduces the price of goods sold between wise traders and men". ${ }^{41}$ Hence, the principle of khiyar al-aib can be applied when the existence of a defect in a product has been discovered by the consumer, regardless of before or after the product purchase process occurs, as long as the defect had existed earlier, which is before the product is accepted by the consumer. In this case, the principle of khiyar al-aib further allows the consumer to choose whether or not to cancel the sale and purchase agreement by returning the product that has been purchased or continue to own the product at a different price. ${ }^{42}$ However, the caveat emptor doctrine will apply and the consumer must be responsible for all defects in a product if the defect is only found after the product is purchased. In other words, the principle of 
khiyar al-aib can still be applied despite if discovery of defects in a product by the consumer occurs after the completion of the purchase process. Meanwhile, in the same situation, the doctrine of caveat emptor places full responsibility on the consumer, and no claim can be made against the seller. Therefore, the principle of khiyar al-aib seemed to protect the consumer right more than the doctrine of caveat emptor.

Islam emphasised the importance of honesty in selling and buying transactions. In this context, Imam asy-Syaukani and Yusuf al-Qaradawi affirmed that Islam obliges the seller to state the condition and nature of a product before selling it, and forbids the act of hiding the defect of the product from the knowledge of the consumer. ${ }^{43}$ Islam has placed a great responsibility on the seller to inform to the consumer about the condition of a product before selling it as well as giving the consumer the right to inspect the product themselves before buying it from the seller based on the principle of khiyar al-aib. In contrast, according to the doctrine of caveat emptor, the seller is not bound to reveal all the conditions of a product including any defects, if any, to the consumer ${ }^{44}$ before the purchase process occurs unless requested by the consumer to do so..$^{45}$ The doctrine is contradicted to the Islamic teachings that advocate sellers, including manufacturers, to always be honest when doing business. The studies submitted that the act of hiding defects that exist in a product with deliberately silences should be avoided by manufacturers and sellers as it will lead to exploitation of consumers.

In Malaysia, the application of khiyar al-aib in the context of consumer law can be analyzed through several statutory provisions under the Consumer Protection Act 1999. For instance, Section 32(1) under Part V of the Consumer Protection Act $1999^{46}$ has provided implied guarantee as to acceptable quality for goods supplied to consumers. One of the criteria considered to determine the acceptable quality is that the goods supplied must be free from defects. ${ }^{47}$ The failure of any goods which is of a substantial character will allow the consumer to reject the goods ${ }^{47}$ or obtain compensation from the supplier. ${ }^{48}$ As such, the above statutory provisions shall be considered as within the principle of khiyar al-ayb. ${ }^{49}$ This is because the researchers found that the legal provisions of consumer law in Malaysia, especially under Part V and Part VI of the Consumer Protection Act 1999 clearly provide consumers the option to reject goods or claim compensation against suppliers if the goods obtained were found to contain defects. On the other hand, the position of Malaysian consumer law specifically with regards to implied guarantee as to acceptable quality is found to be contrary from the caveat emptor application which does not provide equal opportunity to the consumer if a defect is found on an item only after the item is transferred to the consumer.

The above discussion showed that the application of the doctrine of caveat emptor which does not place any responsibility on manufacturers and sellers to disclose any information about the nature and condition of a product before it is sold to consumers is now seen as no longer relevant, and has legal disadvantages based on the above discussion. So, at the next stage, the studies will analyze a legal doctrine that is considered as a better alternative to the caveat emptor doctrine, which is the doctrine of "caveat venditor".

\section{CAVEAT VENDITOR FROM CIVIL PERSPECTIVE}

The development of consumer law from a historical point of view is found to be closely related to the rapid growth of industry, business, economy, as well as the increasing need to revise certain aspects of consumer protection timely. For instance, the existence of the privity of contract is not a requirement in claiming damages for product liability because of a defect against the manufacturer. ${ }^{50}$ This proves consumer law evolves according to the needs of the business community. One of the important developments began in England in 1893, the shift from the doctrine of caveat emptor to the doctrine of caveat venditor (let the seller beware). ${ }^{51}$ The main justification for this change was due to the excess of information possessed by manufacturers and sellers. Both parties had more accurate knowledge of a product's level of quality. ${ }^{52}$ In other words, defective products should not be sold in the market by manufacturers and sellers as it may 
cause loss or physical injury to consumers. As such, the application of the doctrine of caveat venditor hinders the manufacturers and sellers from providing poor quality or unsafe products to consumers.

The application of the doctrine of caveat venditor is applied in the form of implied guarantee as to fitness for particular purpose. ${ }^{53}$ The implied guarantee is provided under section 33 of the CPA $1999 .{ }^{54}$ Based on the case of Grant $v$ Australian Knitting Mills Ltd $^{55}$ the court decided that the seller must beware of the defects of the products. This is because the consumers depend on the skills and information of sellers and manufacturers either expressly or implicitly in acquiring a product. Indirectly, consumers are now no longer burdened with negative effects because of the application of the previous caveat emptor principle, which is seen as more in favor of manufacturers and sellers.

Besides that, the doctrine of caveat venditor complement the consumer right to obtain information. Manufacturers and sellers should provide clear, ${ }^{56}$ accurate, ${ }^{57}$ and sufficient information to facilitate consumers to make the right choice before purchasing a product. ${ }^{58}$ The existence of clear information about a product shall increase consumer confidence to enter a sale and purchase contract. ${ }^{59}$ On the other hand, information that is not complete or ambiguous will make it difficult for consumers to identify the identity, quality and nature of a product. ${ }^{60}$ Pursuant to sections 67(2)(c) and 67(2)(d) of CPA $1999,{ }^{61}$ the existence of a label, instruction, or warning in relation to the method of product usage is part of a customer's entitled expectation in determining whether there are defects in a product or not. In fact, the same provision also applies in product liability law in the United Kingdom based on section 3(2)(a) of the Consumer Protection Act $1987 .{ }^{62}$ In the case of Wilkes $v$ Deputy International Ltd, ${ }^{63}$ the court decided the absence of complete information on a product can be considered as a violation of one of the consumer rights, namely the right to obtain information.

However, from an economic perspective, there is also a view stating that the shift of the doctrine from caveat emptor to caveat venditor increase the cost price of the product. According to this view, manufacturers will allocate higher costs to produce high quality products to prevent legal liability due to production of defective products. Indirectly, the less fortunate are also said to have been denied the right to buy lower quality products at cheaper prices. ${ }^{64}$ Nevertheless, the studies do not intend to prolong the discussion at this stage as the scope of the discussion on the doctrine of caveat venditor from an economic point of view is outside the scope of this study.

It is submitted that usage of the doctrine caveat venditor is part and parcel of product liability law. This is to ensure that manufacturers and sellers emphasized on the quality of their products without underestimating their profit. Furthermore, the doctrine restrains them from taking advantage of the weaker position of the consumer. In addition, the purchase of high-quality products at a reasonable price is preferred than low quality products at low prices which resulted the risk of larger losses or physical injuries because of using such products.

\section{CAVEAT VENDITOR FROM ISLAMIC PERSPECTIVE}

Islam highlighted the importance of honesty in trading. Hence, the doctrine of caveat venditor comply to the requirement of selling and buying in Islamic transactions. Islam emphasizes the aspect of preserving human relations (hablum minannas) in the context of the relationship between manufacturers or sellers with consumers. ${ }^{65}$ Allah SWT says in the Qur'an that is based on Surah An-Nisaa', verse 29 which translated:

O you who believe! Do not consume each other's wealth illicitly, but trade by mutual consent. And do not kill yourselves, for God is Merciful towards you. ${ }^{66}$

Based on the meaning of the above Qur'anic verse, Ibn Taymiyyah of the view that a business's conduct should comply with the requirement of Islamic law, and economic activities should not be separated from moral values according to the Islamic perspective. ${ }^{67}$ In fact, it is undeniable that untruthful individuals will be punished for their wrong doings on the day of the retribution. ${ }^{68}$

Accordingly, Islam against the act of cheating in business. In this context, the seller and manufacturer who hides the defects that 
exist in a product is punishable in Islam. Based on the authentic hadith of the Prophet Muhammad SAW from Abu Hurairah RA which means:

Rasulullah SAW went through an area where there was a pile of food in the market. He put his hand into the food and felt that it was wet. Then he said, "Is this the owner of the food?" The seller said, "O Messenger of Allah, the food is exposed to rain." He said, "Wouldn't it be nice if you put (wet food) at the top so that it can be seen by the public? Anyone who cheats is not from me." ${ }^{\circ 9}$

The above hadith explains that the seller and manufacturer is responsible for showing the defects in the products sold and informed them to the buyer. ${ }^{70}$ Islam forbids the sale of products or goods that have defects to consumers because the perfect condition of a product is paramount in any buying and selling activity.

Based on Imam Syafie's view, apart from the seller, anyone who knows the defect of a product must also inform it to others. ${ }^{71}$ The seller's responsibility to honestly inform the buyer of any defect does not change, even if the defect in the product exists after the product is accepted by the seller from another party. ${ }^{72}$ Therefore, according to Ibn Rusyd, buying and selling activities that contain any uncertainty about the level of safety or quality of a product due to the existence of fraud is prohibited because it may cause loss to consumers. ${ }^{73}$ The responsibility of manufacturers and traders to inform about the existence of any defects to the consumer, and the prohibition on the sale of poor quality products according to Islam in turn may provide justice to consumers in the sale and purchase transaction.

The application of the doctrine of caveat venditor to resolve disputes between manufacturers, sellers and consumers conform to the Islamic teachings which prioritize the value of justice in all matters including dealings. Allah SWT says in Surah Al-Hujuraat, verse 9 which means:

If two groups of believers fight each other, reconcile between them. But if one group aggresses against the other, fight the aggressing group until it complies with God's command. Once it has complied, reconcile between them with justice, and be equitable. God loves the equitable. ${ }^{74}$

Based on the meaning of the above Qur'anic verse, any war or dispute that occurs between certain parties should be resolved well and fairly. ${ }^{75}$ The resolution of a dispute done fairly is highly demanded according to the teachings of Islam, and individuals who are fair in their actions will also be glorified by Allah SWT. Prophet Muhammad SAW said in an authentic hadith which means:

Those who are fair and just will be near to Allah on thrones of light, they are on the right side of Ar-Rahman 'Azza wa Jalla, namely those who are fair and just in their rulings and towards their families and those who are under their authority. ${ }^{76}$

According to the Islamic perspective, leaders in a region or country have been entrusted to enact laws that may serve justice for all parties without involving any element of bias or partiality. The implementation of fair laws, especially consumer law can in turn meet human needs, and eliminate the difficulties that arise in various matters of life. This is also supported by Imam al-Mawardi, who stated that the welfare state cannot be upheld without involving six elements, namely; adherence to religion, strong leaders, comprehensive justice, public safety, lasting prosperity, and accompanied by high hopes. ${ }^{77}$

Based on the above discussion, it is clear that according to Islamic teachings, the responsibility of the manufacturer or seller of goods to reveal the existence of any form of defect in a product, if any, to the consumer is a strong justification, which may support the application of caveat venditor doctrine in consumer law today. In other words, the application of the caveat venditor doctrine is seen as parallel and fair to the consumer, and has similarities to Islamic principles which do not merely place full responsibility on the consumer to identify any defects in a product, if any, before the purchase of a product.

\section{CONCLUSION}

As a whole, the doctrine of caveat emptor is seen to have given advantage to manufacturers and sellers of goods as consumers cannot cancel contracts, return defective goods or claim damages if defects in the goods are only found by the consumer after the completion of the sale and purchase.

Meanwhile, according to the Islamic perspective, the principle of khiyar al-aib is 
seen to have similarities with the doctrine of caveat emptor in terms of giving the consumer the right to inspect a product and notifying the existence of any defect in the product to the seller. However, the principle of khiyar al-aib is seen as more flexible than the caveat emptor doctrine because it still provides an opportunity for consumers to return products that have been purchased if there is any defect.

Subsequently, the negative effects caused by application of the caveat emptor doctrine have led to the formation of caveat venditor doctrine and ultimately counterbalances the position of manufacturers, sellers, and buyers. Manufacturers and sellers can no longer evade liability by placing full responsibility on the consumer to inspect the goods carefully for defects before choosing to buy them. The responsibility taken by manufacturers and traders to convey information about the quality of a product to consumers will in turn provide fairness and guarantee the right of consumers to obtain information.

Lastly, the application of the caveat venditor doctrine also has a strong foundation according to the Islamic perspective. The value of justice is very much emphasized in all aspects of life, including business dealings. Thus, a business practice that causes any oppression or injustice to consumers such as selling a product without revealing its nature and condition clearly is prohibited in Islamic teachings, and should not be practiced by manufacturers, suppliers and sellers to avoid any harm to society as a whole.

\section{ACKNOWLEDGEMENT}

This article is the outcome of a research conducted under a scholarship of study from the Bumiputera/IPTA Academic Training Scheme (SLAB/SLAI) by the Ministry of Education Malaysia and Universiti Malaysia Sarawak.

\section{NOTES}

Section 4 Consumer Protection Act 1999 (Act 599).

Rahmah Ismail et al, Pengguna dan hak untuk mendapatkan maklumat, in Suzanna Mohamed Isa et al (eds.), Pengguna dan Hak Pengguna, Penerbit Universiti Kebangsaan Malaysia, Bangi, 2019, pp 21-22.

3 A.L Ryngelblum et al, 'Accomplishments and relevance of consumer protection organizations' (2017) 25(1) International Journal of Organizational Analysis, p 160.
4 H. Marlyna et al, 'Does the trademark protection regulation protect consumers against counterfeit products? analyzing the theories of trademark and Indonesian trademark law' (2019) 27(3) Pertanika Journal of Social Science and Humanities, p 1869.

5 F. Zeija, 'Consumer protection in Uganda: the law in theory and practice' (2018) 41(4) Journal of Consumer Policy, p 462.

6 J. Kishtwaria et al, 'Consumer awareness regarding legislation organisations and consumer protection laws' (2004) 8(1) Journal of Social Sciences, p 69.

7 A. Sadovnikova et al, 'Consumer protection in postwar Canada: role and contributions of the Consumers' Association of Canada to the public policy process' (2014) 48(2) Journal of Consumer Affairs, p 382.

8 C.E Scruggs et al, "Why leading consumer product companies develop proactive chemical management strategies' (2016) 55(5) Business \& Society, pp 636-637.

9 Kementerian Perdagangan Dalam Negeri dan Hal Ehwal Pengguna et al, 'Keselamatan produk kanak-kanak: Bahagian 1' (2009) (1) Buletin Pengguna, p 11.

10 M. Rizzi, 'The evolution of consumer product safety policy and regulation in India' (2017) 40(3) Journal of Consumer Policy, p 394.

11 F. Ferretti, EU Competition Law, the Consumer Interest and Data Protection: The Exchange of Consumer Information in the Retail Financial Sector, Springer, London, 2014, p 109.

12 J.H Dion et al, 'Consumer protection: exploring private causes of action for victims of data breaches' (2019) 41(2) Western New England Law Review, p 273.

13 P. Cartwright, 'Redress compliance and choice: enhanced consumer measures and the retreat from punishment in the Consumer Rights Act 2015' (2016) 75(2) Cambridge Law Journal, p 271.

14 K.W Chau et al, 'Let the buyer or seller beware: measuring lemons in the housing market under different doctrines of law governing transactions and information' (2011) 54(4) Journal of Law \& Economics, p 348.

15 Aim Edition Sdn Bhd v Ambank (M) Berhad [2020] 5 CLJ 439, p 470; Anuar bin Rozhan \& Ors $v$ Wealth Mentors Sdn Bhd [2020] MLJU 586, p 604; BBMB Kewangan Berhad v Tan Swee Heng \& Anor [2002] MIJU 330, p 342; J.P Naimon et al, 'Caveat emptor or caveat vendor: the evolution of unfairness in federal consumer protection law' (2015) 132(1) Banking Law Journal, p 4.

16 J. Frauley, "Caveat emptor under prudentialism: the case of the Canadian home inspection industry' (2014) 23(2) Social \& Legal Studies, p 198.

17 C.T Leviness, 'Caveat emptor versus caveat venditor' (1942-1943) 7 Maryland Law Review, p 182.

18 W.H Hamilton, 'Ancient maxim caveat emptor' (1931) 40(8) Yale Law Journal, pp 1135 \& 1157.

19 W.A Seavey, 'Caveat emptor as of 1960' (1960) 38(4) Texas Law Review, p 441.

20 J.C Reitz, 'A history of cutoff rules as a form of caveat emptor: part II - from Roman law to the modern civil and common law' (1989) 37(2) American Journal of Comparative Law, p 283.

21 A.M Weinberger, 'Let the buyer be well informed: doubting the demise of caveat emptor' (1996) 55(2) Maryland Law Review, pp 393-395. 
22 Mature Land Sdn Bhd $\mathbf{P}$ Atlantic Plantation Sdn Bhd [2013] 4 MLJ 565, p 571.

23 Autokita Sdn Bhd v Public Bank Berhad [2000] MLJU 834, p 835.

$24 \quad$ Parkinson v Lee [1802] 102 ER 389, p 391.

25 Zeti Zuryani Mohd Zakuan et al, Kontrak pengguna dan keadilan sosial: liabiliti kontraktual pembekal barang di bawah Akta Pelindungan Pengguna 1999, in Rahmah Ismail et al (eds.), Undang-undang Pengguna dan Keadilan Sosial, Penerbit Universiti Kebangsaan Malaysia, Bangi, 2015, p 98.

26 D.J Manderscheid, 'Caveat emptor and the sale of land: the erosion of a doctrine' (2001) 39(2) Alberta Law Review, p 442.

27 Mohd Ma'sum Billah, 'Caveat emptor versus Khiyar al-'Aib: a dichotomy' (1998) 13(3) Arab Law Quarterly, p 281.

$28 \quad[1603] 79$ ER 3, pp 3-4.

$29 \quad[1778] 99$ ER 15, p 16.

30 [1870] 77 U.S. 383, p 384.

31 Keates $v$ The Earl of Cadogan [1851] 138 ER 234, pp $234 \& 236$

32 S.A McEvoy, 'Caveat emptor redux: psychologically impacted property' (1991) 18(2) Western State University Law Review, p 582.

33 D. Pridgen et al, 'Enhancing the flow of information in the marketplace: From caveat emptor to Virginia pharmacy and beyond at the federal trade commission' (1980) 14(4) Georgia Law Review, p 639.

34 A.M Johnson Jr., 'An economic analysis of the duty to disclosure information: lessons learned from the caveat emptor doctrine' (2008) 45(1) San Diego Law Review, pp 82-83 \& 89-91.

$35 \quad$ Hadenan Towpek, 'Konsep khiyar menurut Syeikh Daud bin Abdullah al-Fatani dalam Furu' al-Masa'il' (2013) 21(1) Jurnal Syariah, pp 48-49.

36 Hasri Harun et al, 'Prinsip khiyar (pilihan) dalam undang-undang berkaitan jualan barangan menurut Islam' (2016) 4(1) Al-Qanatir International Journal of Islamic Studies, p 30.

37 Muhammad Noor Hussin et al, Khiyar al-syarat: keperluan perlaksanaannya dalam kontrak perbankan Islam berpandukan Qawa'id Fiqhiyyah, Persidangan Kebangsaan Ekonomi dan Kewangan Islam: Ekonomi Halal, Bangi, Malaysia, 2015, pp 77-78.

38 Hasri Harun et al, 'Prinsip khiyar dalam jualan barangan: kajian terhadap Akta Kontrak 1950 (Akta 136)' (2017) 4(1) International Journal of Islamic and Civilizational Studies, p 31.

39 Md. Habib ur Rahman et al, 'Khiyar al-majlis (option of withdrawal before parting) in sale contract contemporary applications' (2017) 4(2) Turkish Journal of Islamic Economics, p 38-41.

40 Mohd Ma'sum Billah, 'Caveat emptor versus Khiyar al-'Aib: a dichotomy', p 279.

41 Article 338 of Al-Majallah al-Ahkam al-'Adliyyah: The Ottoman Courts Manual (2000), http://legal.pipa.ps/files/ server/ENG\%20Ottoman\%20Majalle\%20(Civil\%20 Law).pdf (30 December 2020).

42 Karuppannan A/1 Chellappan v Chong Lee Chin@ Chong Lai Chun [2000] MLJU 438, pp 291 \& 440.

$43 \quad$ asy-Syaukani, Ringkasan Nailul Authar, Vol. 3, Pustaka Azzam, Jakarta, 2006, p 98; Yusuf al-Qaradawi, The
Lawful and the Prohibited in Islam, K. al-Hilbawi et al (trs), $2^{\text {nd }}$ Edn, Al-Falah Foundation, Cairo, 2001, p 259.

$44 \quad$ Hadland Arthur John and Anor v Audra Elaine Gomez [2009] MLJU 736, p 737.

45 A.M Weinberger, 'Let the buyer be well informed: doubting the demise of caveat emptor', $\mathrm{p} 390$.

$46 \quad$ Section 32(1) Consumer Protection Act 1999 (Act 599).

47 Section 32(2)(iii) Consumer Protection Act 1999 (Act 599).

48 Section 41(1)(b)(i) \& 44(d) Consumer Protection Act 1999 (Act 599).

49 Section 41(1)(b)(ii) \& 41(2) Consumer Protection Act 1999 (Act 599).

50 E. Emroch, 'Caveat emptor to strict liability: one hundred years of products liability law' (1970) 4(2) University of Richmond Law Review, pp 155-156.

51 Ashington Piggeries Ltd \& another v Christopher Hill Ltd [1971] 1 All ER 847, p 879.

52 H. Seshimo, 'A justification for caveat emptor in the secondhand market: risk transfer, enforcement cost and insurance' (2020) 66 Economic Analysis and Policy, p 217.

$53 \quad$ Slater v Finning Ltd [1997] SC (HL) 8, p 19.

$54 \quad$ Section 33 Consumer Protection Act 1999 (Act 599).

55 [1936] AC 85, p 99.

56 M. Donnelly et al, 'Digital content and consumer protection: an empirical study of supplier compliance with consumer information obligations' (2019) 35(6) Computer Law \& Security Review, p 4.

57 L.T. Abe-Matsumoto et al, 'Do the labels of vitamin $\mathrm{A}, \mathrm{C}$, and $\mathrm{E}$ supplements reflect actual vitamin content in commercial supplements?' (2018) 72 Journal of Food Composition and Analysis, p 141.

58 C. Riefa et al, Enforcement and effectiveness of consumer law in the UK, in H.W. Micklitz et al (ed.), Enforcement and Effectiveness of Consumer Law, Springer, Switzerland, 2018, p 674.

59 P. Giliker, 'The Consumer Rights Act 2015: a bastion of European consumer rights' (2017) 37(1) Legal Studies, p 99.

60 M.P Hakim et al, 'The mandatory labeling of genetically modified foods in Brazil: consumer's knowledge, trust, and risk perception' (2020) 132 Food Research International, $\mathrm{p} 8$.

$61 \quad$ Section 67(2)(c) \& section 67(2)(d) Consumer Protection Act 1999 (Akta 599).

62 Section 3(2)(a) Consumer Protection Act 1987 (c 43).

63 [2016] 53 BMLR 91, p 112.

64 J.M Buchanan, 'In defense of caveat emptor' (1970) 38(1) University of Chicago Law Review, pp 66 \& 68.

65 Hamidah Ayob, 'Consumer protection in Islam: an overview' (2017) 20(S1) Malaysian Journal of Consumer Family Economics, p 2.

66 Sheikh Abdullah Basmeih, Tafsir Pimpinan Ar-Rahman Kepada Pengertian Al-Quran (30 Juz): Mushaf Malaysia Rasm Uthmani, $22^{\text {nd }}$ Edn, Darul Fikir, Kuala Lumpur, 2013, p 190.

67 Abdul Azim Islahi, Economic Concepts of Ibn Taimiyah, Islamic Economics Series 12, The Islamic Foundation, Leicester, 1988, p 232.

68 J.A.M Zarabozo, Commentary on the Forty Hadith of al-Nawawi, Vol. 1, Dar Dawat al-Basheer, USA, 2012, p 245 . 
69 Muslim(a), English Translation of Sahih Muslim, The Book of Faith, Chapter 43, Vol. 1, pp 188-189.

70 Mustafa al-Khin et al, Kitab Fikah Mazhab Syafie, Vol. 6, Pustaka Salam Sdn Bhd, Kuala Lumpur, 2005, pp 1313-1314.

71 Mustafa al-Khin et al, Al-Fiqh al-Manhaji Mazhab al-Syafie, Zulkifli Mohamad al-Bakri et al (trs), $2^{\text {nd }}$ Edn, Vol. 4, Jabatan Kemajuan Islam Malaysia, Putrajaya, 2019, p 32.

72 S.M. Ghazanfar, The economic thought of Abu Hamid Al-Ghazali and St Thomas Aquinas: some comparative parallels and links, in S.M Ghazanfar (ed.), Medieval Islamic Economic Thought: Filling the Great Gap in European Economics, RoutledgeCurzon, London, United Kingdom, 2003, p 196.

73 Ibn Rusyd, Bidayatul Mujtahid, Ed. Ahmad Abu al Majdi, Vol. 2, Pustaka Azzam, Jakarta, 2006, p 294.

74 Sheikh Abdullah Basmeih, Tafsir Pimpinan Ar-Rahman Kepada Pengertian Al-Quran (30 Juz): Mushaf Malaysia Rasm Uthmani, p 1385.

75 Abu 'Abdullah Muhammad ibn Ahmad ibn Abu Bakr ibn Fahr al-Ansari al-Qurtubi, Tafsir al-Qurthubi, Tr. Mahmud Hamid Utsman, Vol. 17, Pustaka Azzam, Jakarta, 2015, p 38.

76 Muslim(b), English Translation of Sahih Muslim, The Book of Leadership, Chapter 5, Vol. 5, pp 153-154.

77 A. Gomaa, Justice in Islamic legislation, in R. GriffithJones (ed.), Magna Carta, Religion and the Rule of Law, Cambridge University Press, Cambridge, 2015, pp 181, 186, 191-192.

\section{REFERENCES}

Abdul Azim Islahi. 1988. Economic Concepts of Ibn Taimiyah. Islamic Economics Series 12. Leicester: The Islamic Foundation.

Abe-Matsumoto, L.T., Sampaio, G.R. \& Bastos, D.H.M. 2018. Do the labels of vitamin A, C, and $\mathrm{E}$ supplements reflect actual vitamin content in commercial supplements?. Journal of Food Composition and Analysis 72: 141-149.

Aim Edition Sdn Bhd v Ambank (M) Berhad [2020] 5 CLJ 439

Anuar bin Rozhan \& Ors $v$ Wealth Mentors Sdn Bhd [2020] MLJU 586

Ashington Piggeries Ltd \& another v Christopher Hill Ltd [1971] 1 All ER 847

Autokita Sdn Bhd v Public Bank Berhad [2000] MLJU 834

Barnard v Kellogg [1870] 77 U.S. 383

BBMB Kewangan Berhad v Tan Swee Heng \& Anor [2002] MLJU 330

Buchanan, J.M. 1970. In defense of caveat emptor. University of Chicago Law Review 38(1): 64-73.

Cartwright, P. 2016. Redress compliance and choice: enhanced consumer measures and the retreat from punishment in the Consumer Rights Act 2015. Cambridge Law Journal 75(2): 271-300.

Chandelor v Lopus [1603] 79 ER 3

Chau, K.W. \& Choy, L.H.T. 2011. Let the buyer or seller beware: measuring lemons in the housing market under different doctrines of law governing transactions and information. Journal of Law \& Economics 54(4): 347-366.

Dion, J.H. \& Smith, N.M. 2019. Consumer protection: exploring private causes of action for victims of data breaches. Western New England Law Review 41(2): 253-286.

Donnelly, M. \& White, F. 2019. Digital content and consumer protection: an empirical study of supplier compliance with consumer information obligations. Computer Law \& Security Review 35(6): 1-12.

Emroch, E. 1970. Caveat emptor to strict liability: one hundred years of products liability law. University of Richmond Law Review 4(2): 155-173.

Ferretti, F. 2014. EU Competition Law, the Consumer Interest and Data Protection: The Exchange of Consumer Information in the Retail Financial Sector. London: Springer.

Frauley, J. 2014. Caveat emptor under prudentialism: the case of the Canadian home inspection industry. Social \& Legal Studies 23(2): 195-213.

Ghazanfar, S.M. 2003. The economic thought of Abu Hamid al-Ghazali and St Thomas Aquinas: some comparative parallels and links. In Ghazanfar, S.M (ed.). Medieval Islamic Economic Thought: Filling the Great Gap in European Economics, pp 184-208. London: RoutledgeCurzon.

Giliker, P. 2017. The Consumer Rights Act 2015: a bastion of European consumer rights. Legal Studies 37(1): 78-102.

Gomaa, A. 2015. Justice in Islamic legislation. In Griffith-Jones, R. (ed.). Magna Carta, Religion and the Rule of Law, pp 177-195. Cambridge: Cambridge University Press.

Grant v Australian Knitting Mills Ltd [1936] AC 85

Hadenan Towpek. 2013. Konsep khiyar menurut Syeikh Daud bin Abdullah al-Fatani dalam Furu“ al-Masa'il. Jurnal Syariah 21(1): 43-62.

Hadland Arthur John and Anor v Audra Elaine Gomez [2009] MLJU 736

Hakim, M.P., Zanetta, L.D, Oliveira, J.M.D. \& Cunha, D.T.D. 2020. The mandatory labeling of genetically modified foods in Brazil: consumer's knowledge, trust, and risk perception. Food Research International 132: 1-10.

Hamidah Ayob. 2017. Consumer protection in Islam: an overview. Malaysian Journal of Consumer Family Economics 20(S1): 1-10.

Hamilton, W.H. 1931. Ancient maxim caveat emptor. Yale Law Journal 40(8): 1133-1187.

Hasri Harun, Shofian Ahmad \& Ruzian Markom. 2016. Prinsip khiyar (pilihan) dalam undangundang berkaitan jualan barangan menurut Islam. Al-Qanatir International Journal of Islamic Studies 4(1): 28-38.

Hasri Harun, Shofian Ahmad \& Ruzian Markom. 2017. Prinsip khiyar dalam jualan barangan: kajian 
terhadap Akta Kontrak 1950 (Akta 136). International Journal of Islamic and Civilizational Studies 4(1): 27-40.

Ibn al-Hajjaj, Abul Hussain Muslim. 2007a. English Translation of Sahih Muslim. Tr. Nasiruddin al-Khattab. Vol. 1. Riyadh: Maktaba Dar-us-Salam.

Ibn al-Hajjaj, Abul Hussain Muslim. 2007b. English Translation of Sahih Muslim. Tr. Nasiruddin al-Khattab. Vol. 5. Riyadh: Maktaba Dar-us-Salam.

Ibn Rusyd. 2006. Bidayatul Mujtahid. Ed. Ahmad Abu Al Majdi. Vol. 2. Jakarta: Pustaka Azzam.

Johnson Jr., A.M. 2008. An economic analysis of the duty to disclosure information: lessons learned from the caveat emptor doctrine. San Diego Law Review 45(1): 79-132.

Karuppannan A/1 Chellappan v Chong Lee Chin@ Chong Lai Chun [2000] MLJU 438

Keates v The Earl of Cadogan [1851] 138 ER 234

Kementerian Perdagangan Dalam Negeri dan Hal Ehwal Pengguna \& Gabungan Persatuan-Persatuan Pengguna Malaysia. 2009. Keselamatan produk kanak-kanak: Bahagian 1. Buletin Pengguna Januari: 11.

al-Khin, Mustafa., al-Bugha, Mustafa \& asy-Syarbaji, Ali. 2005. Kitab Fikah Mazhab Syafie, Vol. 6, Kuala Lumpur: Pustaka Salam Sdn Bhd.

al-Khin, Mustafa., al-Bugha, Mustafa \& asy-Syarbaji, Ali. 2019. Al-Fiqh al-Manhaji Mazhab al-Syafie. Tr. Zulkifli Mohamad al-Bakri \& rakan-rakan. $2^{\text {nd }}$ Edn. Vol. 4. Putrajaya: Jabatan Kemajuan Islam Malaysia.

al-Majallah al-Ahkam al-'Adliyyah: The Ottoman Courts Manual. 2000. http://legal.pipa.ps/files/ server/ENG\%20Ottoman\%20Majalle\%20(Civil\%20 Law).pdf [30 December 2020].

Kishtwaria, J., Sharma, A., Vyas, N. \& Sharma, S. 2004. Consumer awareness regarding legislation organisations and consumer protection laws. Journal of Social Sciences 8(1): 69-72.

Leviness, C.T. 1942-1943. Caveat emptor versus caveat venditor. Maryland Law Review 7: 177-200.

Manderscheid, D.J. 2001. Caveat emptor and the sale of land: the erosion of a doctrine. Alberta Law Review 39(2): 441-452.

Marlyna, H. \& Sardjono, A. 2019. Does the trademark protection regulation protect consumers against counterfeit products? analyzing the theories of trademark and Indonesian trademark law. Pertanika Journal of Social Science and Humanities 27(3): 1865-1877.

Mature Land Sdn Bhd v Atlantic Plantation Sdn Bhd [2013] 4 MLJ 565

McEvoy, S.A. 1991. Caveat emptor redux: psychologically impacted property. Western State University Law Review 18(2): 579-588.

Md. Habib ur Rahman, Muhammad Amanullah \& Mohammad Mohiuddin. 2017. Khiyar al-majlis (option of withdrawal before parting) in sale contract contemporary applications. Turkish Journal of Islamic Economics 4(2): 37-50.

Mohd. Ma'sum Billah. 1998. Caveat emptor versus Khiyar al-'Aib: a dichotomy. Arab Law Quarterly 13(3): 278-300.

Mohd Murshidi Mohd Noor, Ishak Suliaman, Khadher Ahmad, Fauzi Deraman, Mustaffa Abdullah, Faisal Ahmad Shah, Mohd Yakub Zulkifli Mohd Yusoff, Monika Munirah Abd Razzak, Jilani Touhami Meftah, Sedek Ariffin, Ahmad K. Kasar \& Mohd Roslan Mohd Nor. 2013. The rights of khiyar (option) in the issue of consumerism in Malaysia. Middle-East Journal of Scientific Research 13(2): 154-161.

Muhammad Noor Hussin, Sanep Ahmad \& Hairunnizam Wahid. 2015. Khiyar al-syarat: keperluan perlaksanaannya dalam kontrak perbankan Islam berpandukan Qawa'id Fiqhiyyah. Prosiding Persidangan Kebangsaan Ekonomi dan Kewangan Islam, pp. 73-80.

Naimon, J.P., Jensen, K.D., Stapleton, C.M. \& Leonhardt, S. 2015. Caveat emptor or caveat vendor: the evolution of unfairness in federal consumer protection law. Banking Law Journal 132(1): 3-20.

Parkinson v Lee [1802] 102 ER 389

Pridgen, D. \& Pridgen, I.L. 1980. Enhancing the flow of information in the marketplace: from caveat emptor to Virginia pharmacy and beyond at the federal trade commission. Georgia Law Review 14(4): 635-680.

al-Qaradawi, Yusuf. 2001. The Lawful and the Prohibited in Islam. Tr. al-Hilbawi, K., Siddiqi, M. \& Shukri, S. $2^{\text {nd }}$ Edn. Cairo: Al-Falah Foundation.

al-Qurtubi, Abu 'Abdullah Muhammad ibn Ahmad ibn Abu Bakr ibn Fahr al-Ansari. 2015. Tafsir al-Qurthubi. Tr. Mahmud Hamid Utsman. Vol. 17. Jakarta: Pustaka Azzam.

Rahmah Ismail, Sakina Shaik Ahmad Yusoff \& Suzanna Mohamed Isa. 2019. Pengguna dan hak untuk mendapatkan maklumat. In Suzanna Mohamed Isa \& Sakina Shaik Ahmad Yusoff (eds.). Pengguna dan Hak Pengguna, pp 20-23. Bangi: Penerbit Universiti Kebangsaan Malaysia.

Reitz, J.C. 1989. A history of cutoff rules as a form of caveat emptor: part II - from Roman law to the modern civil and common law. American Journal of Comparative Law 37(2): 247-300.

Riefa, C. \& Willett C. 2018. Enforcement and effectiveness of consumer law in the UK. In Micklitz, H.W. \& Saumier G. (eds.). Enforcement and Effectiveness of Consumer Law, pp 673-695. Switzerland: Springer.

Rizzi, M. 2017. The evolution of consumer product safety policy and regulation in India. Journal of Consumer Policy 40(3): 389-412.

Ryngelblum, A.L. \& Vianna, N. 2017. Accomplishments and relevance of consumer protection organizations. 
International Journal of Organizational Analysis 25(1): 160-174.

Sadovnikova, A., Mikhailitchenko, A. \& Shapiro, S.J. 2014. Consumer protection in post war Canada: role and contributions of the Consumers' Association of Canada to the public policy process. Journal of Consumer Affairs 48(2): 380-402.

Scruggs, C.E. \& Buren, H.J.V. 2016. Why leading consumer product companies develop proactive chemical management strategies. Business \& Society 55(5): 635-675.

Seavey, W.A. 1960. Caveat emptor as of 1960. Texas Law Review 38(4): 439-449.

Seshimo, H. 2020. A justification for caveat emptor in the second-hand market: risk transfer, enforcement cost and insurance. Economic Analysis and Policy 66: $217-235$.

Sheikh Abdullah Basmeih. 2013. Tafsir Pimpinan Ar-Rahman Kepada Pengertian Al-Quran (30 Juz): Mushaf Malaysia Rasm Uthmani. $4^{\text {th }}$ Edn. Kuala Lumpur: Darul Fikir.

Slater v Finning Ltd [1997] SC (HL) 8

Stuart v Wilkins [1778] 99 ER 15

asy-Syaukani. 2006. Ringkasan Nailul Authar. Vol. 3. Jakarta: Pustaka Azzam.

Weinberger, A.M. 1996. Let the buyer be well informed: doubting the demise of caveat emptor. Maryland Law Review 55(2): 387-424.

Wilkes v Depuy International Ltd [2016] 53 BMLR 91

Zarabozo, J.A.M. 2012. Commentary on the Forty Hadith of al-Nawawi. Vol. 1. USA: Dar Dawat al-Basheer.
Zeija, F. 2018. Consumer protection in Uganda: the law in theory and practice. Journal of Consumer Policy 41(4): 455-471.

Zeti Zuryani Mohd Zakuan, Sakina Sakina Ahmad Yusoff \& Rahmah Ismail. 2015. Kontrak pengguna dan keadilan sosial: liabiliti kontraktual pembekal barang di bawah Akta Pelindungan Pengguna 1999. In Undang-undang Pengguna dan Keadilan Sosial, edited by Rahmah Ismail, Sakina Sakina Ahmad Yusoff \& Shamsuddin Suhor, 94-113. Bangi: Penerbit Universiti Kebangsaan Malaysia.

Muhammad Hafiz Mohd. Shukri

Lecturer

Faculty of Economics and Business

Universiti Malaysia Sarawak

Jalan Ensurai, 94300

Kota Samarahan, Sarawak

Email: msmhafiz@unimas.my

Rahmah Ismail

Associate Professor

Faculty of Law

Universiti Kebangsaan Malaysia

43600 Bangi, Selangor

Email: irahmah@ukm.edu.my

Ruzian Markom

Associate Professor

Faculty of Law

Universiti Kebangsaan Malaysia

43600 Bangi, Selangor

Email: ruzian@ukm.edu.my 